\title{
1 Standardisation of an Agroinfiltration Protocol for Eggplant 2 Fruits and Proving its Usefulness by Over-expressing the 3 SmHQT Gene
}

\section{Prashant Kaushik*}

Instituto de Conservación y Mejora de la Agrodiversidad Valenciana, Universitat Politècnica de València, 46022 Valencia, Spain

* Correspondence: prakau@ doctor.upv.es; Tel.: +34-963-877-000

Abstract: Eggplant is a fruit vegetable of family Solanaceae, and eggplant fruits are of different shape and sizes that render them as an ideal system for metabolic engineering. Here, we have developed an agroinfiltration protocol for the transient expression of a gene in the eggplant fruit using GUS bearing; pCAMBIA1304 vector. Thereafter, to prove the effectiveness of the developed protocol, we have used the eggplant hydroxycinnamoyl CoA-quinate transferase (SmHQT), which is the central enzyme studied to increase the chlorogenic acid content, in a gene construct with the specific promoter in a plant transformation vector (pBIN19). Also, in our cassette, we also co-expressed the P19 protein of Tomato bushy stunt virus (native promoter) to overexpress the protein. Overall, using the protocol, the chlorogenic content was increased by more than two folds in the transgenic tissues.

Keywords: agroinfiltration; eggplant; fruits; agrobacterium; SmHQT

\section{Introduction}

Phenolic acids are among the most common phenolic compounds produced by different plant species [1,2]. Eggplant (Solanum melongena L.) belongs to Solanaceae and contains high concentrations of phenolic acids, which are beneficial for human health and development. Phenolics of eggplant flesh have proved useful for the protection against several diseases like diabetes, cancer and arthritis [3-5]. Increasing the content of these phenolic compounds especially chlorogenic acid is among the major breeding objectives for eggplant. In the eggplant flesh, the chlorogenic acid forms an ester as 5-caffeoylquinic acid, and it makes up to 90 percent of total phenolics found in the eggplant flesh. [6]. Moreover, it also forms more and lesser spotted esters such as 3-caffeoylquinic acid and 4-caffeoylquinic acid $[7,8]$. Increases in the concentrations of these phenolic compounds take place in response to environmental stress and under insect pest and pathogen infestations $[9,10]$.

Nevertheless, cultivated eggplant has far less phenolic acids than its several wild relatives [3]. Therefore, several breeding approaches were undertaken in the past and are still ongoing to improve the phenolic acid content of cultivated eggplant, e.g. introgression breeding and backcrossing [11]. Unfortunately, all these techniques can not completely get rid of unwanted genes such as those are associated with the wild species, e.g. prickles, bitterness, alkaloids, etc. [12]. These genes are not uncommon to wild relatives and landraces, which use these defense mechanisms against predators and diseases [13]. Therefore, the use of highly precise genome editing approaches and the use of transgenics technology cannot be overlooked, as they restrict the introduction of external DNA to a specific gene sequence or fragment of interest. With transgenic methods, only the specific sequence will be delivered in the genome so that it precisely expresses only the phenotypes associated with that gene [14-16].

Transgenic plants are routinely used to understand the molecular genetic function of a gene [17]. The plant transformation method based on Agrobacterium tumefaciens is amongst the most popular techniques of plant transformations and is widely applied to several commercially important crop plants, like maize and tomatoes [18,19]. Even with lots of new techniques adding, agrobacterium-based methods are more popular than any other technique used for the transgene delivery in plants. This is because this method is comparatively cheap and has a high transformation efficiency [20]. Further, agroinfiltration is a method of injecting agrobacterium with a gene of interest along with a T-DNA vector in the plant tissues, which allows the transient expression of a gene for various purposes. Compared to large time investment in stable transformation, agroinfiltration provides a rapid assay and can further help to elucidate its functions via studies on its function or involvement in the different pathways [21]. 
modifications [24]. Also, the plant with a transient protein is ready for the evaluation within a few days as compared to the months reserved by the stable transformation method. Also, with stable transformation method, there can even be a high probability of bias because of chromosomal positions and epigenetic mechanisms by the constructs [25]. Overall, agroinfiltration has become a method of popular choice for assigning a gene function. This method is well established in several fruit-bearing plants like tomato, strawberry, melon and cucumber [26-29].

The chlorogenic acid synthesis pathway is known in eggplant, and the enzymes are also mapped on eggplant genetic map, and their genetic inheritance is know [30]. The hydroxycinnamoyl CoA-quinate (HQT) is the central enzyme studied to increase the chlorogenic acid content in Solanaceae and other families. The function of eggplant transferase (SmHQT) enzyme is the esterification of transferase 4-coumaroyl CoA and quinic acid to form CGA, and further to provide the entry molecule of the flavonoid pathway [31,32]. Furthermore, HQT is well studied in other solanaceous vegetables; in the case of tomato, over-expression of HQT resulted in the overproduction of chlorogenic acid by around two-fold [33]. In contrast, the suppression of HQT gene resulted in the reduction of chlorogenic acid content by $90 \%$ [34].

In eggplants, there is no established protocol to follow for the agroinfiltration assays. Therefore, the objectives of this study were to establish and standardise an effective agroinfiltration protocol for the eggplant fruit and thereafter by applying that protocol to the study the expression pattern in the eggplant genome transiently over-expressing of SmHQT gene. In our cassette, we also co-expressed the P19 protein of tomato bushy stunt virus, which is well used for the characterisation and native expression desired protein in the plant tissues. P19 prevents the post-transcriptional gene silencing (PTGS) of the infiltrated leaves which could result from plant response to the pathogenic, and in consequence, the agroinfiltrated tissue can keep on expressing the desired protein product [35,36].

\section{Methodology and Outcomes}

\subsection{Development of eggplant HQT gene construct with the specific promoter in a plant transformation vector}

Genomic DNA was isolated from eggplant sample and used for amplification of the HQT gene along with its specific native promoter. Primers were designed and synthesised for specific amplification of the SmHQT fragments. The gene was amplified as two fragments; fragment- 1 contained the promoter region and exon 1 while fragment- 2 contained the second exon. Both fragments were combined in cloning protocol. The complete gene was then cloned in a pUC based cloning vector (pBlueScript; at HindIII and BamHI restriction sites) and sequence confirmed. 


\section{PCR calibration}

76 The fragments (FI-593bp and FII-874bp) were PCR amplified separately and assembled to obtain a full-length 77 SmHQT gene (1467bp). The full-length PCR product was then gel purified before being used for the restriction 78 digestion and ligation.

79 Table 1. PCR conditions.

\begin{tabular}{lc}
\hline Component & Amount \\
\hline Template (gDNA; 50ng) & $1.0 \mu \mathrm{l}$ \\
Forward Primer $(100 \mathrm{ng} / \mu \mathrm{l})$ & $2.0 \mu \mathrm{l}$ \\
Reverse primer $(100 \mathrm{ng} / \mu \mathrm{l})$ & $2.0 \mu \mathrm{l}$ \\
10X Assay Buffer & $5.0 \mu \mathrm{l}$ \\
dNTPs $(10 \mathrm{mM})$ & $2.0 \mu \mathrm{l}$ \\
ChromTaq $(3 \mathrm{U} / \mu \mathrm{l})$ & $0.5 \mu \mathrm{l}$ \\
Water & $37.5 \mu \mathrm{l}$ \\
Total reaction volume & $50.0 \mu \mathrm{l}$ \\
\hline
\end{tabular}

Table 2. PCR cycle conditions:

\begin{tabular}{|l|l|l|l|l|}
\hline $94^{\circ} \mathrm{C}$ & $94^{\circ} \mathrm{C}$ & $\mathrm{Ta}^{\circ} \mathrm{C}^{*}$ & $72^{\circ} \mathrm{C}$ & $72^{\circ} \mathrm{C}$ \\
\hline $5 \mathrm{~min}$ & $30 \mathrm{sec}$ & $40 \mathrm{sec}$ & $1 \mathrm{~min}$ & $10 \mathrm{~min}$ \\
\hline & \multicolumn{3}{|c|}{35 cycles } & \\
\hline
\end{tabular}

$81 * \mathrm{Ta}^{\circ} \mathrm{C}-$ Fragment I ( $\left.32 \% \mathrm{GC}\right): 50^{\circ} \mathrm{C} \mathrm{Ta}^{\circ} \mathrm{C}-$ Fragment II (49\% GC): $52^{\circ} \mathrm{C}$

82 Cloning and sequencing

83 The optimised gene was then cloned in the cloning vector (pBlueScript KS+ vector) at HindIII/BamHI sites. Probable

84 clones were screened by restriction digestion and were further confirmed by sequencing. 
85

86 Table 3. Digestion conditions for PCR product and vector:

\begin{tabular}{ll}
\hline Component & Amount \\
\hline DNA & $4 \mu \mathrm{g}$ \\
HindIII & 36 units \\
BamHI & 36 units \\
10X Assay buffer & $40 \mu \mathrm{l}$ \\
Water & $\mathrm{X}^{*} \mu \mathrm{l}$ \\
Total reaction volume & $400 \mu \mathrm{l}$ \\
\hline
\end{tabular}

$87 *$ Based on the final volume of the reaction. The reaction was incubated at $37^{\circ} \mathrm{C}$ for $2 \mathrm{hrs}$.

88 Table 4. Ligation of insert into the vector.

\begin{tabular}{ll}
\hline Component & Amount \\
\hline Vector & $100 \mathrm{ng}$ \\
& $100 \mathrm{ng}-150 \mathrm{ng}$ \\
Insert & \\
& \\
Chromous Quick Ligase (Cat\# -MFE14; Chromous Biotech & $1 \mu \mathrm{l}$ \\
Pvt. Ltd, Bangalore, India) & $10 \mu \mathrm{l}$ \\
$2 \mathrm{X}$ Chromous Quick Ligase assay buffer & $\mathrm{X}^{*} \mu \mathrm{l}$ \\
Water & $20 \mu \mathrm{l}$ \\
\hline
\end{tabular}

$89 *$ Based on the final volume of the reaction. Reaction was incubated at room temperature for 30 min. 


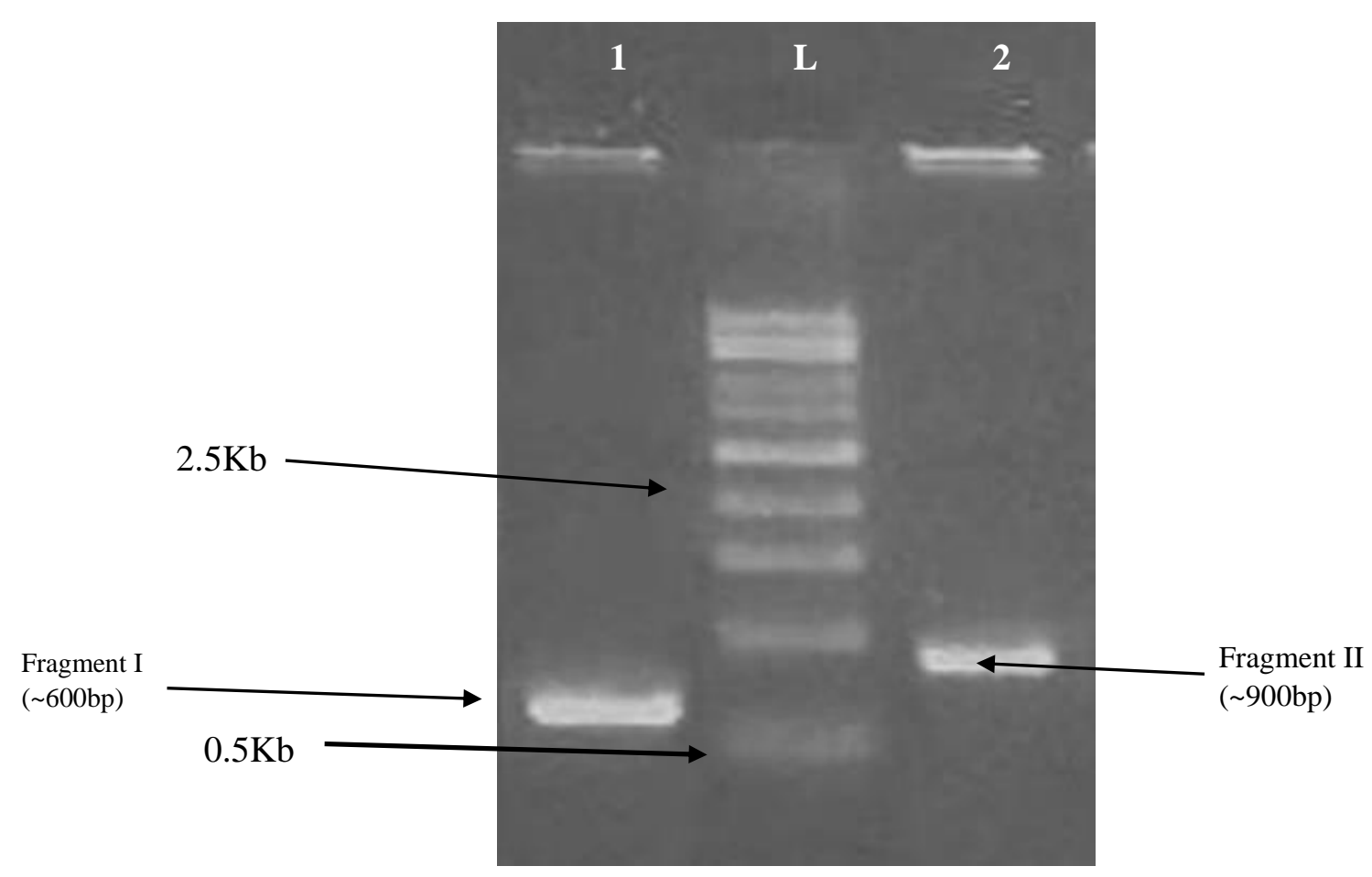

91 Figure 1. PCR fragment I and II loaded on a 1\% agarose gel.

Transformation in competent cells

93 The $10 \mu \mathrm{l}$ of the ligation reaction mix was transformed into $100 \mu \mathrm{l}$ of $\mathrm{DH} 5 \alpha$ competent cells. Incubated at $4^{\circ} \mathrm{C}$ (ice)

94 for $30 \mathrm{~min}$ and heat shock was given at $42^{\circ} \mathrm{C}$ for $45 \mathrm{sec}$. Quick chilled on ice for $2 \mathrm{~min}$ and volume made-up to $1 \mathrm{ml}$

95 with $\mathrm{LB}$ broth. Incubated at $37^{\circ} \mathrm{C}$ for $1 \mathrm{hr}$ in shaking incubator for recovery. After that, cells were pelleted at 3000

96 rpm for 3min; Supernatant discarded and cells plated on LB-agar plates with ampicillin; X-gal and IPTG (AXI) plate.

97 Plates incubated overnight at $37^{\circ} \mathrm{C}$.

98 AXI Plate: To $100 \mathrm{ml}$ of LB add $100 \mu 1$ ampicillin (Initial concentration: 100mg/ml), $120 \mu 1 \mathrm{X}$-gal (Initial 99 concentration: $100 \mathrm{mg} / \mathrm{ml}$ ), $24 \mu \mathrm{l}$ IPTG (Initial concentration: $1 \mathrm{M}$ ).

100 Screening for clones

101 Probable clones were screened by restriction digestion and checked for the release of the gene. Positive clones were 102 sequence confirmed and processed further for Sub-Cloning in the expression vector (pBIN19, Addgene) (Figure S1). 
103

104

105

106

107

108

The pBS+SmHQT clone was restriction digested (HindIII/BamHI); released gene was then cloned into pBIN19 at (HindIII/BamHI). Further, these probable clones were screened and confirmed by restriction digestion. Briefly, the Clone DNA ( $4 \mu \mathrm{g}$ of plasmid DNA is required to discharge at least $1 \mu \mathrm{g}$ of insert) was taken and digested with HindIII/BamHI.

Table 5. Conditons of sub-cloning.

\begin{tabular}{ll}
\hline Component & Amount \\
\hline DNA & $4 \mu \mathrm{g}$ \\
HindIII & 36 units \\
BamHI & 36 units \\
10X Assay buffer & $40 \mu 1$ \\
Water : & $X^{*} \mu 1$ \\
Total reaction volume & $400 \mu 1$ \\
\hline
\end{tabular}

*Based on the final volume of the reaction

110 The released insert was gel eluted and ligated to pBIN19 vector at HindIII/BamHI sites. $10 \mu 1$ of the ligation 111 reaction mix was transformed into $100 \mu \mathrm{l}$ of DH5 $\alpha$ competent cells. Incubated at $4{ }^{\circ} \mathrm{C}$ (ice) for $30 \mathrm{~min}$ and heat 112 shock given at $42^{\circ} \mathrm{C}$ for $45 \mathrm{sec}$. Quick chilled on ice for $2 \mathrm{~min}$ and volume made up to $1 \mathrm{ml}$ with LB. Incubated 113 at $37^{\circ} \mathrm{C}$ for $1 \mathrm{hr}$ in a shaking incubator. After that, cells were pelleted at $3000 \mathrm{rpm}$ for $3 \mathrm{~min}$; Supernatant 114 discarded and cells plated on classical kanamycin plate. Plates incubated overnight at $37^{\circ} \mathrm{C}$.

115 Screening for clones:

116 - Probable clones were screened by restriction digestion and checked for the release of the gene.

- The SmHQT gene was finally sequence confirmed and used further for all agroinfiltration experiments.

119 Overlapping PCR-based technique was used for development of p19 construct with its native promoter. The 120 gene was synthetically synthesized following recursive PCR based protocol described elsewhere [37]. The 121 optimised genes were then cloned in a cloning vector (pEASY-blunt vector) and amplified; sequence confirmed. 122 The sequence-confirmed gene was sub-cloned in the pBIN19 vector and confirmed by sequencing. 


\section{Cloning and sequencing}

124 The optimised gene was then cloned in the cloning vector (pUC57 vector; Addgene, Spain) at HindIII/BamHI

125 sites. Probable clones were screened by restriction digestion and further confirmed by sequencing.

126 Table 6. Digestion of PCR product and vector:

\begin{tabular}{ll}
\hline Component & Amount \\
\hline DNA & $4 \mu \mathrm{g}$ \\
$\begin{array}{l}\text { HindIII (Cat\# -REN011A;Chromous Biotech } \\
\text { Pvt. Ltd, Bangalore, India) }\end{array}$ & 36 units \\
$\begin{array}{l}\text { BamHI (Cat\# -REN004A;Chromous Biotech } \\
\text { Pvt. Ltd, Bangalore, India) }\end{array}$ & 36 units \\
10X Assay buffer & $40 \mu 1$ \\
Water : & $\mathrm{X}^{*} \mu \mathrm{l}$ \\
Total reaction volume & $400 \mu \mathrm{l}$ \\
\hline
\end{tabular}

$127 *$ Based on the final volume of the reaction. Reaction was incubated at $37^{\circ} \mathrm{C}$ for $2 \mathrm{hrs}$.

128 Table 7. Ligation with vector:

\begin{tabular}{ll}
\hline Component & Amount \\
\hline Vector & $100 \mathrm{ng}$ \\
Insert & $65 \mathrm{ng}-70 \mathrm{ng}$ \\
$\begin{array}{l}\text { Chromous Quick Ligase (Cat\# -MFE14; Chromous } \\
\text { Biotech Pvt. Ltd, Bangalore, India) }\end{array}$ & $1 \mu \mathrm{l}$ \\
$2 \mathrm{X}$ Chromous Quick Ligase assay buffer & $10 \mu \mathrm{l}$ \\
Water & $\mathrm{X}^{*} \mu \mathrm{l}$ \\
Total reaction volume & $20 \mu \mathrm{l}$ \\
\hline
\end{tabular}

$129 *$ Based on the final volume of the reaction. Reaction was incubated at room temperature for $30 \mathrm{~min}$.

130 Transformation in competent cells

131 - $10 \mu \mathrm{l}$ of the ligation reaction mix was transformed into $100 \mu \mathrm{l}$ of DH5 $\alpha$ competent cells. 
132 - Incubated at $4^{\circ} \mathrm{C}$ (ice) for $30 \mathrm{~min}$ and heat shock given at $42^{\circ}$ for $45 \mathrm{sec}$.

133 - Quick chilled on ice for 2 min and volume made-up to $1 \mathrm{ml}$ with LB broth.

134 - Incubated at $37^{\circ} \mathrm{C}$ for $1 \mathrm{hr}$ in shaking incubator for recovery.

135 - The cells were then pelleted at 3000rpm for 3min; Supernatant discarded and cells plated on AXI plate.

136 - Plates incubated overnight at $37^{\circ} \mathrm{C}$.

137 AXI Plate: To 100ml of LB add $100 \mu \mathrm{l}$ ampicillin (Initial concentration: 100mg/ml), $120 \mu 1 \mathrm{X}$-gal (Initial 138 concentration: $100 \mathrm{mg} / \mathrm{ml}), 24 \mu \mathrm{l}$ IPTG (Initial concentration: $1 \mathrm{M}$ ).

139 Screening for clones:

140 - Probable clones were screened by restriction digestion and checked for the release of the gene.

141 - Positive clones were sequence confirmed and processed further for Sub-Cloning in the expression 142 vector (pBIN19).

143 Sub-cloning of sequence confirmed p19 in pBIN19

144

145

146

147

148

149

- $\quad$ The pUC57+p19 clone was restriction digested (HindIII/BamHI); released gene was then cloned into pBIN19 at (HindIII/BamHI).

- $\quad$ Probable clones were screened \& confirmed by restriction digestion.

The release of the insert from sequence confirmed pBS clone and subcloning in pBIN19:

- Clone DNA (4 $\mu \mathrm{g}$ of plasmid DNA is required to release at least one $\mu \mathrm{g}$ of insert) was taken and digested with HindIII/BamHI

\begin{tabular}{ll}
\hline Component & Amount \\
\hline DNA & $4 \mu \mathrm{g}$ \\
HindIII & 36 units \\
BamHI & 36 units \\
10X Assay buffer & $40 \mu 1$ \\
Water : & $\mathrm{X}^{*} \mu 1$ \\
Total reaction volume & $400 \mu \mathrm{l}$ \\
\hline
\end{tabular}

*Based on the final volume of the reaction.

151 - The released insert was gel eluted and ligated to pBIN19 vector at HindIII/BamHI sites.

152 - $10 \mu \mathrm{l}$ of the ligation reaction mix was transformed into $100 \mu \mathrm{l}$ of DH5 $\alpha$ competent cells. $\bullet$ Incubated at $4{ }^{\circ} \mathrm{C}$ (ice) for $30 \mathrm{~min}$ and heat shock given at $42^{\circ} \mathrm{C}$ for $45 \mathrm{sec}$. 
- Quick chilled on ice for $2 \mathrm{~min}$ and volume made up to $1 \mathrm{ml}$ with $\mathrm{LB}$.

- Incubated at $37^{\circ} \mathrm{C}$ for $1 \mathrm{hr}$ in a shaking incubator.

- The cells were then pelleted at 3000rpm for 3min; Supernatant discarded and cells plated on Kanamycin plate.

- Plates incubated overnight at $37^{\circ} \mathrm{C}$.

Screening for clones

- Probable clones were screened by restriction digestion and checked for the release of the gene.

- The p19 gene was finally sequence confirmed and used further for all Agroinfiltration experiments (Figure S2).

\subsection{Use of a control construct (GUS bearing) and agroinfiltration in eggplant fruit}

- pCAMBIA 1304 was procured and used for standardisation of agroinfiltration protocols.

- Vector details are attached to the supplementry (Figure S3).

Observation:

- The plates showed mixed colonies indicating contamination and hence competent cells were prepared further using the freeze-thaw protocol.

Preparation of freeze/thaw competent cells and transformation

Agrobacterium tumefaciens strain GV3101 was streaked on an LB agar plate in the presence of Rifampicin $\left(20 \mathrm{mg} / \mathrm{ml}\right.$ stock) and Gentamycin $\left(50 \mathrm{mg} / \mathrm{ml}\right.$ stock) and incubated at $28^{\circ} \mathrm{C}$ for $24-48 \mathrm{Hrs}$. After that, a single colony was picked from an LB-agar plate, and $5 \mathrm{ml}$ starter culture is prepared by growing in at $28^{\circ} \mathrm{C}$ for 24 $48 \mathrm{Hrs}$, in a shaker incubator. The $100 \mathrm{ml}$ of LB was inoculated with $1 \%$ of inoculums of overnight grown agrobacterium culture (in presence of antibiotics) and grown to an O.D of 0.7. Further, the culture was spun down with $4^{\circ} \mathrm{C}$ for 10 minutes at $5000 \mathrm{rpm}$. The pellet was resuspended in $10 \mathrm{ml}$ of ice-cold sterile $20 \mathrm{mM} \mathrm{CaCl}_{2}$ and spun at $4^{\circ} \mathrm{C}$ for 10 minutes at $5000 \mathrm{rpm}$. The cell pellet was re-suspended in $1 \mathrm{ml}$ of ice-cold sterile $20 \mathrm{mM}$ $\mathrm{CaCl}_{2}$, and $100 \mu \mathrm{l}$ aliquots were made. Around $1 \mu \mathrm{g}$ plasmid DNA was added to the cells and the cells/DNA mix was frozen on dry ice for 5 minutes. The frozen cells/DNA mix was thawed to room temperature for 5-10 minutes and the mix was transferred to a tube containing $2 \mathrm{ml} \mathrm{LB}$ medium and incubated with shaking at $28^{\circ} \mathrm{C}$ for 2-4 hours. The cells were pelleted at 3000rpm for 5 mins and plated on selective LB-agar plates. The LB agar plates were made with Rifampicin; Gentamycin and Kanamycin. Plates incubation was at $28^{\circ} \mathrm{C}$ for $3-4$ days.

Observation:

- The plates showed individual colonies and the same were replica plated for future use.

- The colonies were screened by PCR for confirmation and once confirmed for the presence of plasmid DNA, were further sub-cultured for use in agroinfiltration experiments.

Agroinfiltration of eggplant fruits

- Loop full culture of agrobacterium clone harbouring the recombinant plasmid was inoculated in $5 \mathrm{ml}$ LB broth containing the respective antibiotics and grown at $28^{\circ} \mathrm{C}$ for overnight. 
190

191

192

193

194

195

196

197

198

199

200

201

202

203
- $\quad$ The overnight grown culture was sub-culture in a fresh $5 \mathrm{ml} \mathrm{LB}$ broth and allowed to grow to an O.D of 1.6 at $600 \mathrm{~nm}$.

- The cells were then pelleted at $6000 \mathrm{rpm}$ for $5 \mathrm{mins}$ at room temperature.

- $\quad$ The cell pellet was re-suspended in infiltration medium (sterile water) to retain the O.D at 1.6.

- The final agrobacterium suspension was used for agroinfiltration of Eggplant fruits.

- A $2 \mathrm{ml}$ syringe with a needle was used to inject the Eggplant fruits at 10-15 spots and allowed to grow for 3 to 10 days after infiltration (DAI).

- The fruit samples were harvested from 3 days onwards and screened for positive expression of the GUS gene by X-Gluc staining.

- $1 \mathrm{mM} X-G l u c$ was prepared according to standard protocol, and the fruit sections were stained for 30mins at $37^{\circ} \mathrm{C}$ and visualised under a light microscope (LYZER LT-1610X).

- $\quad$ The fruits 3 DAI showed best X-Gluc staining, as compared with the 7 DAI and 10 DAI fruits.

- Also, post 5 DAI the fruits started to show yellowing in the fruit colour. And hence the 3 DAI was finalised for use on the SmHQT gene studies.

\subsection{Agroinfiltration of SmHQT+p19 in Eggplant fruits}

- $\quad$ For the agroinfiltration experiment of SmHQT, the pBIN19 clones harbouring the SmHQT gene and p19 gene respectively were transformed in agrobacterium using the above-mentioned freeze/thaw protocol.

- The agrobacterium is harbouring the pBIN19+SmHQT (Figure S4), and pBIN19+p19 clones, respectively, were screened by colony PCR using vector-specific primers.

- The PCR positive colonies were replica plated and sub-cultured for further use in agroinfiltration experiments.

- The agroinfiltration was performed as per the standardised protocol mentioned above, and the fruits were harvested at 3 DAI.

- Thereafter, fruits were harvested and stored in $-80^{\circ} \mathrm{C}$ for further studies.

Note. The agrobacterium cultures harbouring only the pBIN19+SmHQT and pBIN19+p19 were used at a ratio of 1:1 for all agroinfiltration experiments. 


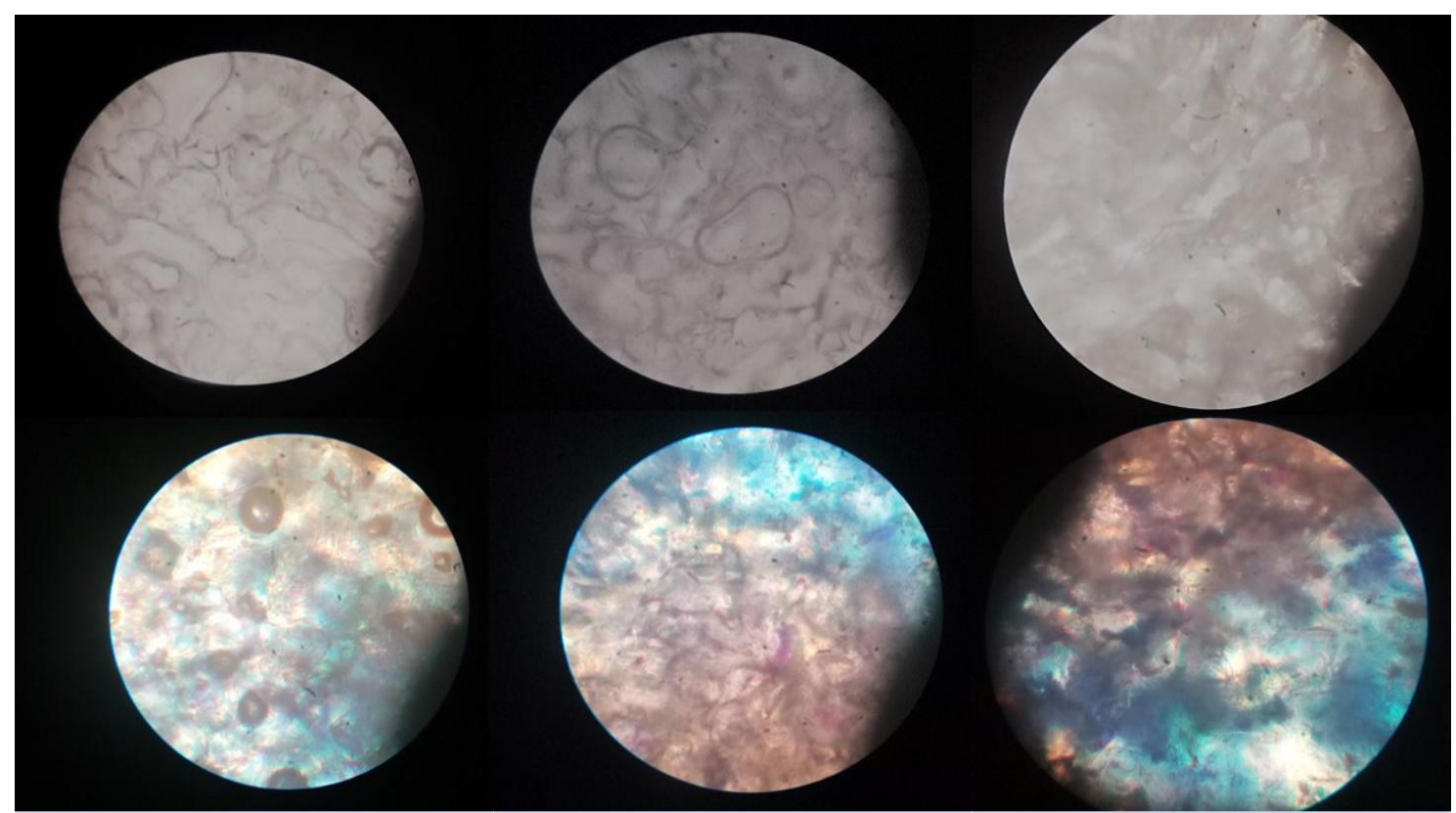

217 Figure 2. Comparison of control (above) and transgenic (below) fruit slices via X-Gluc staining.

For the confirmation of the transgenic tissues HPLC based analysis was performed based on the already standardised protocol for the estimation of chlorogenic acid content in the eggplant defined elsewhere [3]. Briefly, The lyophilised fruit tissues $(0.1 \mathrm{~g})$ were agitated with a $2 \mathrm{ml}$ methanol:water $(80: 20, \mathrm{v} / \mathrm{v})$ along with $0.1 \%(\mathrm{w} / \mathrm{v}$ ) of 2,3-tert-Butyl-4-hydroxyanisole (BHT) [30]. After that, the mixture was filtered through 0.2- $\mu \mathrm{m}$ size membrane filters. High-performance liquid chromatography (HPLC) system was used to compare the control and the transgenic fruit samples. The assessment of CGA content was performed on to a 1220 Infinity LC Technique (Agilent Technologies, Santa Clara, CA, USA) [30]. The outcomes were computed by the OpenLAB CDS ChemStation Edition package (Agilent Technologies) following the manufacturer guidelines. The results of HPLC analysis are presented in the Figure 4. Percentage of peak area in the chromatogram was determined based on the chlorogenic acid peak area and the total peak area of other phenolic acids (hydroxycinnamic acid conjugates). The total area increased for other hydroxycinnamic acid conjugates and thereby, resulting in an overall lower percentage of area (Figure 4A). The transgenic showed more than two times of chlorogenic acid content, whereas, area under chlorogenic acid curve was lesser than the control (Figure $4 \mathrm{~B}$ ). While, the peak area also increased in the transgenic sample (Figure $4 \mathrm{C}$ ).

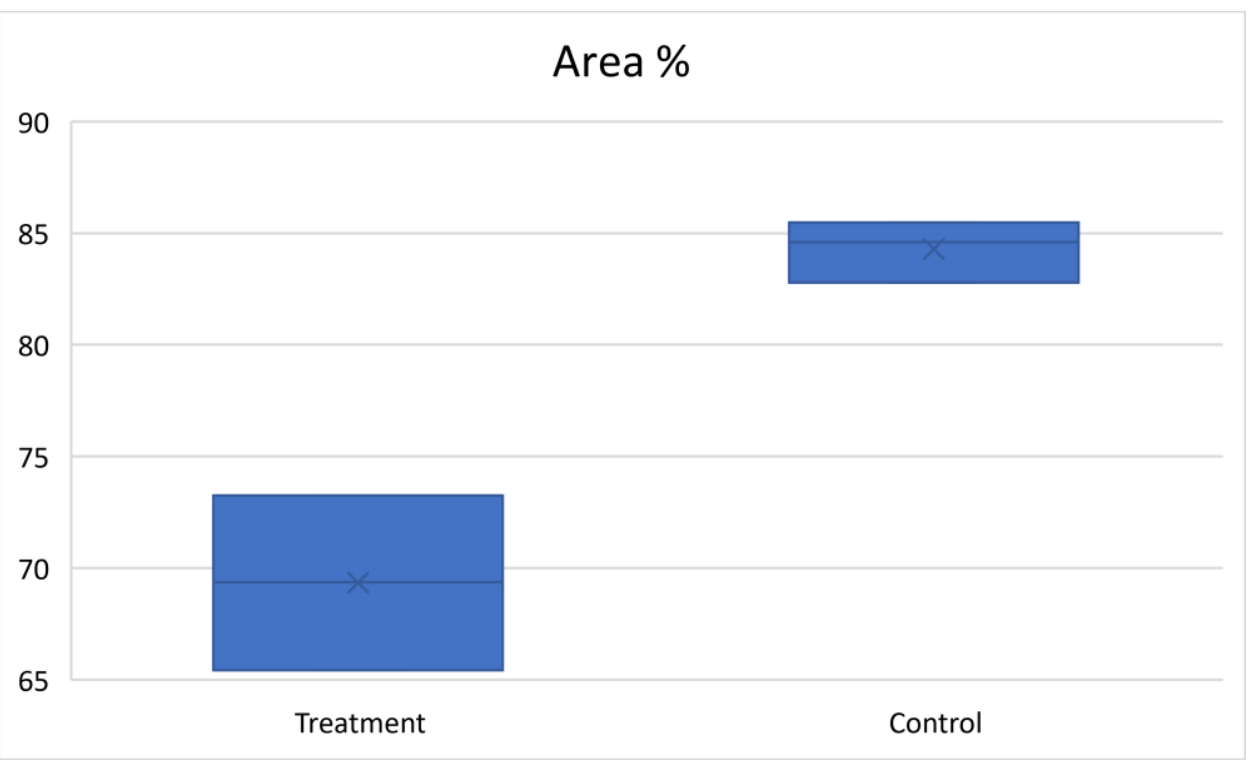




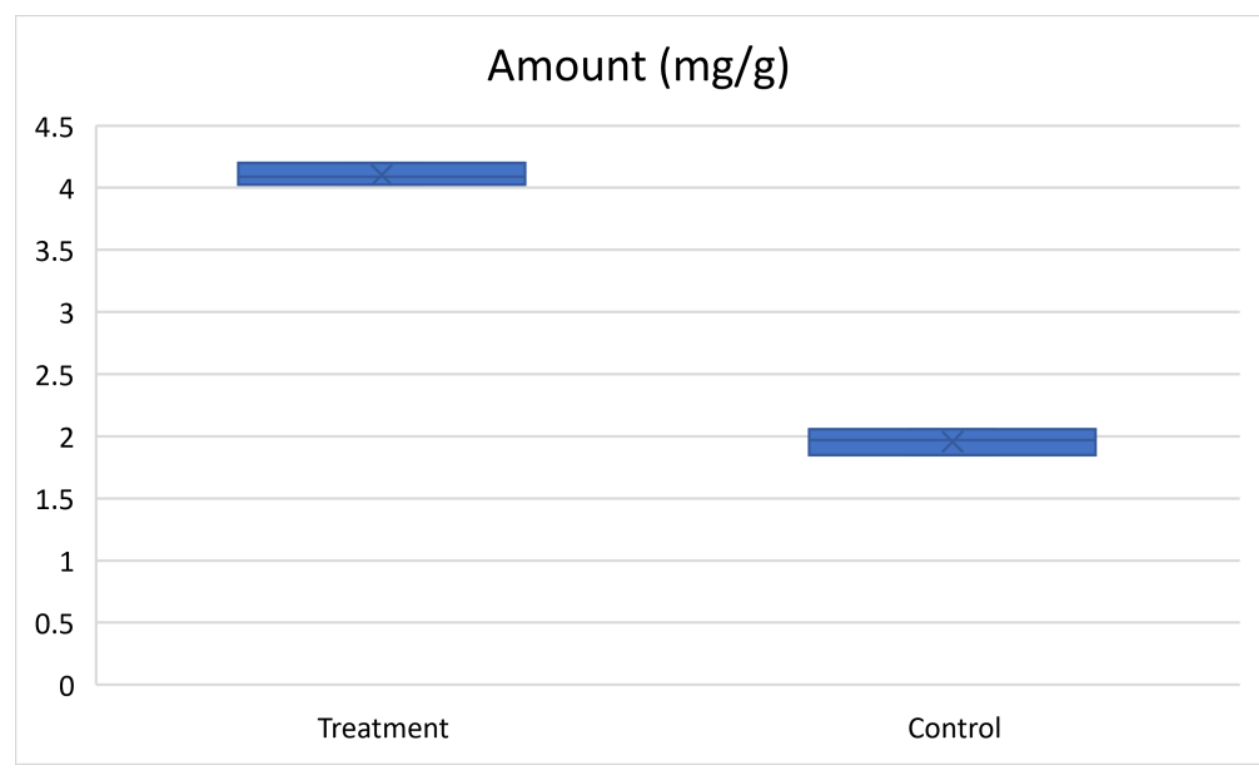

(B)

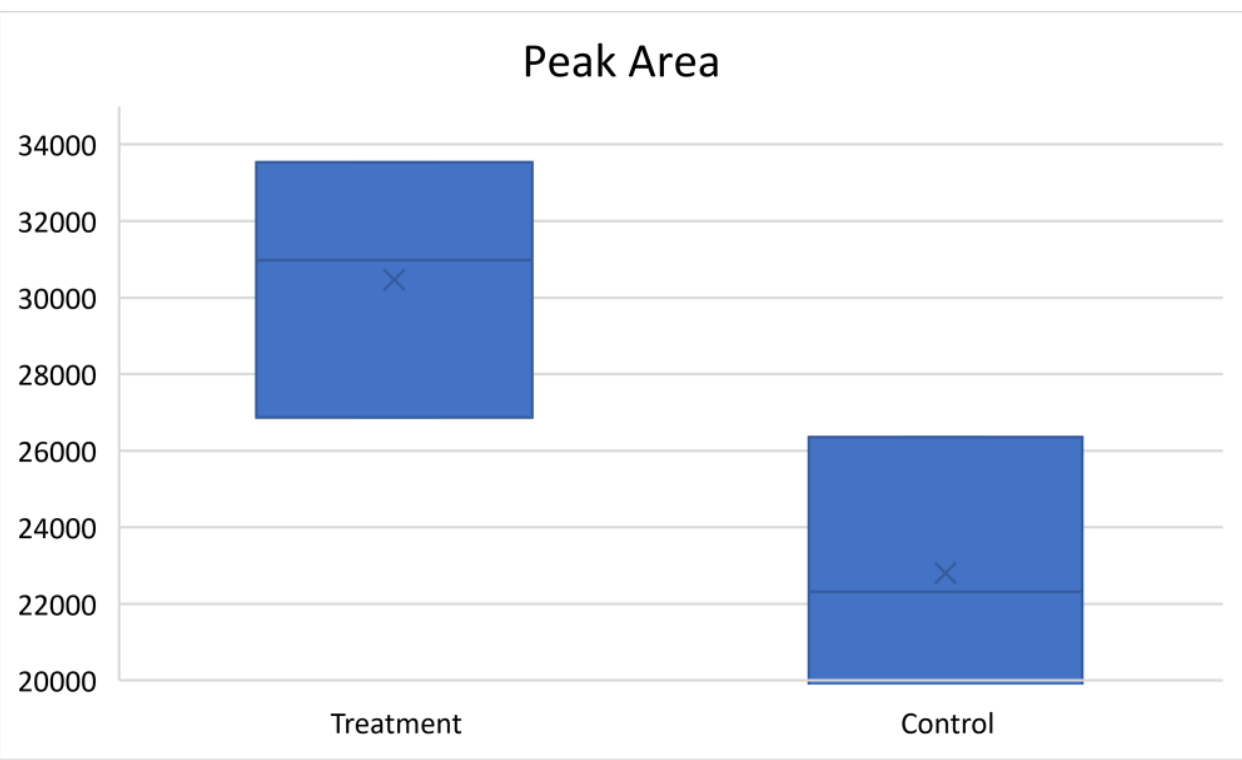

(C)

238 Figure 3. HPLC analysis based difference among control vs treatment, for area (A, \%), amount (B, mg/g) and 239 peak area $(\mathrm{C})$.

\section{Conclusions}

241 Agroinfiltration, a method developed here is user-friendly, and this transient gene expression system designed for the eggplant fruits will be useful in swiftly and precisely identifying the fruit tissue-specific gene functions along with protein production. Further, if this technique is coupled with plant omics tools, e.g. with transcriptomics (RNA-seq), it will provide the detailed information of gene activity, and with metabolomics, an overall shift in the fruit metabolism because of the insert of a particular gene. Also, this method could apply to other members of family Solanaceae those were never discovered from the genetic transformation viewpoint. To avoid the traditional long breeding cycle and to transfer the gene of interest rapidly without even worrying about the unnecessary genomic region linked to a gene, the genetic engineering methods are of great choice. In planta, if we have to study the gene function of a gene at the specific organ of the plant, the agroinfiltration methods are used. In eggplant, there is not any standard agroinfiltration protocol to measure the gene expression. 
Although, eggplant produces several fruits that is a system to mass produce a specific protein. The biosynthetic pathway of chlorogenic acid is well known in eggplant. While the hydroxycinnamoyl CoA-quinate (HQT) is the central enzyme studied to increase the chlorogenic acid content in Solanaceae and other families. The function of eggplant transferase (SmHQT) enzyme is the esterification of 4-coumaroyl CoA and quinic acid to form CGA, and further to provide the entry molecule of the flavonoid pathway. In our study, we have developed the agroinfiltration method for the eggplant fruit, and successfully agroinfiltrated the eggplant fruits. Further, we have tested the efficiency of our protocol with natively over-expressing the smHQT gene in the eggplant fruit's flesh.

Supplementary Materials: Figure S1: Vector map pBIN19, Figure S2: Representation of vector pBIN19 with p19 (protein of tomato bushy stunt virus), Figure S3: Vector details of pCAMBIA 1304 used for the standardization of agroinfiltration protocols, Figure S4: Representation of vector pBIN19+SmHQT construct.

Conflicts of Interest: The author declare no conflict of interest.

\section{References}

1. Goleniowski, M.; Bonfill, M.; Cusido, R.; Palazón, J. Phenolic Acids. In Natural Products; Springer, Berlin, Heidelberg, 2013; pp. 1951-1973 ISBN 978-3-642-22143-9.

2. Harborne, J. B. Phenolic Compounds. In Phytochemical Methods; Springer, Dordrecht, 1984; pp. 37-99 ISBN 978-94-010-8956-2.

3. Kaushik, P.; Gramazio, P.; Vilanova, S.; Raigón, M. D.; Prohens, J.; Plazas, M. Phenolics content, fruit flesh colour and browning in cultivated eggplant, wild relatives and interspecific hybrids and implications for fruit quality breeding. Food Res. Int. 2017, 102, 392-401, doi:10.1016/j.foodres.2017.09.028.

4. Kaushik, P. Application of Conventional, Biotechnological and Genomics Approaches for Eggplant (Solanum melongena.L). Breeding with a Focus on Bioactive Phenolics. 2019, doi:10.4995/Thesis/10251/122295.

5. Rice-Evans, C. A.; Miller, N. J.; Paganga, G. Structure-antioxidant activity relationships of flavonoids and phenolic acids. Free Radic. Biol. Med. 1996, 20, 933-956.

6. Plazas, M.; Andújar, I.; Vilanova, S.; Hurtado, M.; Gramazio, P.; Herraiz, F. J.; Prohens, J. Breeding for Chlorogenic Acid Content in Eggplant: Interest and Prospects. Notulae Botanicae Horti Agrobotanici Cluj-Napoca 2013, 41, 26-35, doi:10.15835/nbha4119036.

7. Stommel, J. R.; Whitaker, B. D. Phenolic Acid Content and Composition of Eggplant Fruit in a Germplasm Core Subset. J. Amer. Soc. Hort. Sci. 2003, 128, 704-710.

8. Meyer, R. S.; Whitaker, B. D.; Little, D. P.; Wu, S.-B.; Kennelly, E. J.; Long, C.-L.; Litt, A. Parallel reductions in phenolic constituents resulting from the domestication of eggplant. Phytochemistry 2015, 115, 194-206, doi:10.1016/j.phytochem.2015.02.006.

9. Lattanzio, V.; Lattanzino, V. M. T.; Cardinali, A. Role of phenolics in the resistance mechanisms of plants against fungal pathogens and insects. 2006, 661, 23-67.

10. Shivashankar, S.; Sumathi, M.; Krishnakumar, N. K.; Rao, V. K. Role of phenolic acids and enzymes of phenylpropanoid pathway in resistance of chayote fruit (Sechium edule) against infestation by melon fly, Bactrocera cucurbitae. Annals of Applied Biology 166, 420-433, doi:10.1111/aab.12194.

11. Kaushik, P. Line $\times$ Tester Analysis for Morphological and Fruit Biochemical Traits in Eggplant (Solanum melongena L.) Using Wild Relatives as Testers. Agronomy 2019, 9, 185, doi:10.3390/agronomy9040185.

12. Kaushik, P.; Andújar, I.; Vilanova, S.; Plazas, M.; Gramazio, P.; Herraiz, F. J.; Brar, N. S.; Prohens, J. Breeding Vegetables with Increased Content in Bioactive Phenolic Acids. Molecules 2015, 20, 18464 18481, doi:10.3390/molecules201018464. 
13. Kaushik, P.; Prohens, J.; Vilanova, S.; Gramazio, P.; Plazas, M. Phenotyping of Eggplant Wild Relatives and Interspecific Hybrids with Conventional and Phenomics Descriptors Provides Insight for Their Potential Utilization in Breeding. Front Plant Sci 2016, 7, 677, doi:10.3389/fpls.2016.00677.

14. Abdallah, N. A.; Prakash, C. S.; McHughen, A. G. Genome editing for crop improvement: Challenges and opportunities. GM Crops Food 2016, 6, 183-205, doi:10.1080/21645698.2015.1129937.

15. for, G. P. at Garn. P. is an advocate; GARNet, researcher in plant sciences H. is the co-ordinator for; Arabidopsis, a network for the U.; Community, W. P. R. Genome editing in plants Available online: https://blogs.biomedcentral.com/on-biology/2015/08/07/genome-editing-plants/ (accessed on Oct 22, 2018).

16. Araki, M.; Ishii, T. Towards social acceptance of plant breeding by genome editing. Trends Plant Sci. 2015, 20, 145-149, doi:10.1016/j.tplants.2015.01.010.

17. Ahmad, P.; Ashraf, M.; Younis, M.; Hu, X.; Kumar, A.; Akram, N. A.; Al-Qurainy, F. Role of transgenic plants in agriculture and biopharming. Biotechnol. Adv. 2012, 30, 524-540, doi:10.1016/j.biotechadv.2011.09.006.

18. Yadava, P.; Abhishek, A.; Singh, R.; Singh, I.; Kaul, T.; Pattanayak, A.; Agrawal, P. K. Advances in Maize Transformation Technologies and Development of Transgenic Maize. Front Plant Sci 2017, 7, doi:10.3389/fpls.2016.01949.

19. Saini, D. K.; Kaushik, P. Visiting eggplant from a biotechnological perspective: A review. Scientia Horticulturae 2019, 253, 327-340, doi:10.1016/j.scienta.2019.04.042.

20. Hwang, H.-H.; Yu, M.; Lai, E.-M. Agrobacterium-Mediated Plant Transformation: Biology and Applications. The Arabidopsis Book 2017, e0186, doi:10.1199/tab.0186.

21. Chen, Q.; Lai, H.; Hurtado, J.; Stahnke, J.; Leuzinger, K.; Dent, M. Agroinfiltration as an Effective and Scalable Strategy of Gene Delivery for Production of Pharmaceutical Proteins. Adv Tech Biol Med 2013, 1, doi:10.4172/atbm.1000103.

22. Ahmad, A.; Pereira, E. O.; Conley, A. J.; Richman, A. S.; Menassa, R. Green biofactories: recombinant protein production in plants. Recent Pat Biotechnol 2010, 4, 242-259.

23. Petrovská, B.; Šebela, M.; Doležel, J. Inside a plant nucleus: discovering the proteins. J Exp Bot 2015, 66, 1627-1640, doi:10.1093/jxb/erv041.

24. Plasson, C.; Michel, R.; Lienard, D.; Saint-Jore-Dupas, C.; Sourrouille, C.; de March, G. G.; Gomord, V. Production of recombinant proteins in suspension-cultured plant cells. Methods Mol. Biol. 2009, 483, 145-161, doi:10.1007/978-1-59745-407-0_9.

25. Khan, S.; Ullah, M. W.; Siddique, R.; Nabi, G.; Manan, S.; Yousaf, M.; Hou, H. Role of Recombinant DNA Technology to Improve Life. Int J Genomics 2016, 2016, doi:10.1155/2016/2405954.

26. Huang, H.; Wang, Z.; Cheng, J.; Zhao, W.; Li, X.; Wang, H.; Zhang, Z.; Sui, X. An efficient cucumber (Cucumis sativus L.) protoplast isolation and transient expression system. Scientia Horticulturae 2013, 150, 206-212, doi:10.1016/j.scienta.2012.11.011.

27. Orzaez, D.; Mirabel, S.; Wieland, W. H.; Granell, A. Agroinjection of Tomato Fruits. A Tool for Rapid Functional Analysis of Transgenes Directly in Fruit. Plant Physiology 2006, 140, 3-11, doi:10.1104/pp.105.068221.

28. Cao, S.; Chen, H.; Zhang, C.; Tang, Y.; Liu, J.; Qi, H. Heterologous Expression and Biochemical Characterization of Two Lipoxygenases in Oriental Melon, Cucumis melo var. makuwa Makino. PLOS ONE 2016, 11, e0153801, doi:10.1371/journal.pone.0153801. 
29. Guidarelli, M.; Baraldi, E. Transient transformation meets gene function discovery: the strawberry fruit case. Front. Plant Sci. 2015, 6, doi:10.3389/fpls.2015.00444.

30. Kaushik, P. Genetic Analysis for Fruit Phenolics Content, Flesh Color, and Browning Related Traits in Eggplant (Solanum melongena). International Journal of Molecular Sciences 2019, 20, 2990, doi:10.3390/ijms20122990.

31. Docimo, T.; Francese, G.; Ruggiero, A.; Batelli, G.; De Palma, M.; Bassolino, L.; Toppino, L.; Rotino, G. L.; Mennella, G.; Tucci, M. Phenylpropanoids Accumulation in Eggplant Fruit: Characterization of Biosynthetic Genes and Regulation by a MYB Transcription Factor. Front Plant Sci 2015, 6, 1233, doi:10.3389/fpls.2015.01233.

32. Kaushik, P.; Saini, D. K. Sequence Analysis and Homology Modelling of SmHQT Protein, a Key Player in Chlorogenic Acid Pathway of Eggplant. bioRxiv 2019, 599282, doi:10.1101/599282.

33. Niggeweg, R.; Michael, A. J.; Martin, C. Engineering plants with increased levels of the antioxidant chlorogenic acid. Nat. Biotechnol. 2004, 22, 746-754, doi:10.1038/nbt966.

34. Payyavula, R. S.; Shakya, R.; Sengoda, V. G.; Munyaneza, J. E.; Swamy, P.; Navarre, D. A. Synthesis and regulation of chlorogenic acid in potato: Rerouting phenylpropanoid flux in HQT-silenced lines. Plant Biotechnology Journal 13, 551-564, doi:10.1111/pbi.12280.

35. Canto, T.; Uhrig, J. F.; Swanson, M.; Wright, K. M.; MacFarlane, S. A. Translocation of Tomato Bushy Stunt Virus P19 Protein into the Nucleus by ALY Proteins Compromises Its Silencing Suppressor Activity. J Virol 2006, 80, 9064-9072, doi:10.1128/JVI.00953-06.

36. Voinnet, O.; Rivas, S.; Mestre, P.; Baulcombe, D. An enhanced transient expression system in plants based on suppression of gene silencing by the p19 protein of tomato bushy stunt virus. Plant J. 2003, 33, 949-956.

37. Hoover, D. M.; Lubkowski, J. DNAWorks: an automated method for designing oligonucleotides for PCR-based gene synthesis. Nucleic Acids Res 2002, 30, e43. 